УДК 101.1

$10.17213 / 2075-2067-2020-4-168-172$

\title{
КАПИТАЛИЗМ И СОВРЕМЕННЫЕ СОЦИАЛЬНЫЕ ТЕОРИИ
}

\author{
(C) 2020 г. П. В. Павлов, В. С. Любченко
}

\section{Южно-Российский государственный политехнический университет (НПИ) имени М. И. Платова, г. Новочеркасск, Россия}

Целью статьи является анализ проблем капитализма и его тенденций в свете современного сочиального знания.

Методология исследования: статья базируется на анализе текстов современных теоретиков, обращчающихся к критическому изучению сочиальных и экономических аспектов современного капитализма (Дж. Дин, Н. Срничек и А. Уильямс, Т. Пикетти).

Результаты исследования. В статье делается вывод о том, что проблема современного капитализма становится предметом серьезной критической рефлексии в ряде теорий, рассматривающих его через призму таких проблем, как «неофеодализм», альтернативные проекты посткапитализма и «посттрудового» общества, соичильно-экономическое неравенство. Важной проблемой в этих теориях являются дискуссии о «безусловном базовом доходе» и прогрессивном налоге на капитал.

Ключевые слова: капитализм; неофеодализм; посткапитализм; посттрудовое общество; неравенство; прогрессивный налог на капитал.

\section{CAPITALISM AND MODERN SOCIAL THEORIES}

\section{(C) 2020 P. V. Pavlov, V. S. Lyubchenko}

\section{Platov South Russian State Polytechnic University (NPI), Novocherkassk, Russia}

The purpose of the article is to analyze the problems of capitalism and its tendencies in the light of modern social knowledge.

Research methodology: the article is based on the analysis of the texts of modern theorists who turn to the critical study of the social and economic aspects of modern capitalism (J. Dean, N. Srnicek and A. Williams, T. Piketty).

Research results. The article concludes that the problem of modern capitalism is becoming the subject of serious critical reflection in a number of theories that consider it through the prism of such problems as «neo-feudalism», alternative projects of post-capitalism and "post-labor» society, socio-economic inequality. An important issue in these theories is the debate about «unconditional basic income» and progressive capital taxes.

Key words: capitalism; neo-feudalism; postcapitalism; post-labor society; inequality; progressive capital tax.

Введение. Что представляет собой современный капитализм и каковы его тенденции? Характерно, что столь популярные (и весьма длительное время) теории «постиндустриального» общества, в котором «сглаживаются» основные противоречия капитализма, ус- 
тупают место более критической рефлексии, которая обращена к негативным тенденциям современного общества, в различных «дискурсах» обозначаемого как «коммуникативный капитализм» [3], «капитализм платформ» [6] и т.д. Рассмотрим проблему тенденций современного капитализма в зеркале идей современных западных теоретиков, таких как Джоди Дин, Ник Срничек и Алекс Уильямс. При этом особое место в статье уделим анализу проблемы социально-экономического неравенства в исследовании Томаса Пикетти, посвященному современному капиталу.

Современный капитализм и «неофеодализм». С точки зрения Джоди Дин, тенденции современного («коммуникативного») капитализма таковы, что он может переродиться в «нечто худшее», а именно в неофеодализм. Капитализм, пишет Дж. Дин, «может превратиться... в неофеодализм новых сеньоров и крепостных, микроэлиты платформенных миллиардеров и гигантского сектора услуг или сектора прислуги» [2]. Дело в том, что современную капиталистическую систему все более пронизывают феодальные элементы. Так, капитал все менее вкладывается в производство, но «накапливается на счетах, растрачивается или перераспределяется в качестве ренты» [2]. Стоимость все менее участвует в создании новой стоимости; накопление капитала происходит уже не только через товарное производство, но и через ренту, а также способы принуждения, напоминающие феодальные. Наращивание основного капитала (валоризация), как пишет Дин, выходит «за пределы фабрики», приобретая все более непрозрачный и спекулятивный характер.

При этом Дж. Дин выделяет следующие основные характеристики «неофеодализма»: 1) «парцелляция суверенитета»; 2) «иерархия и экспроприация с участием новых сеньоров и крестьян»; 3) наличие привилегированных городов и «заброшенной глубинки»; 4) «чувство незащищенности и катастрофизм» [2]. Так, «парцелляция суверенитета», которая была существенной чертой феодализма (на это обращал внимание, например, П. Андерсон [1]), в современном «неофеодализме» выражается в том, что универсальность права заменяется частными интересами крупнейших компаний. Как пишет Дин, «при не- офеодализме правовая фикция буржуазного государства, определяемая нейтральностью закона, действующего для свободных и равных индивидов, развеивается...» [2].

Существенной проблемой современности оказывается и стремительный рост неравенства, который приводит к появлению новых «крестьян» и новых «сеньоров», новой «глобальной аристократии», которая включает в себя не только финансовые институты, но и крупнейшие «цифровые платформы». Эти «неофеодальные» тенденции усиливаются все более нарастающим разрывом между городом как центром деловой жизни и пригородом, провинцией, деревней («заброшенной глубинкой»), а также апокалиптическими настроениями, которые были весьма характерны для феодального средневековья. В целом же главная тенденция современного капиталистического общества, стремящегося к «неофеодализму», - стремительно растущее социально-экономическое неравенство, все более увеличивающийся разрыв между богатыми и бедными. При этом именно феодальные отношения, как справедливо напоминает Дж. Дин, - это прежде всего отношения неравенства.

Проект «посттрудового» общества. Но существуют ли какие-либо альтернативные проекты общественного развития? Так, Ник Срничек и Алекс Уильямс в своей книге «Изобретая будущее» [7] предлагают альтернативу современному капитализму с его неолиберальной идеологией. Авторы говорят о посткапиталистическом проекте как проекте «посттрудового» общества. Существенными характеристиками этого общества, как отмечают Н. Срничек и А. Уильямс, являются следующие основные моменты: автоматизация труда, сокращение рабочей недели, безусловный базовый доход, который не просто обеспечивает удовлетворение минимальных потребностей, но обеспечивает и гарантирует «приемлемый уровень жизни».

При этом базовый доход рассматривается как всеобщий, предоставляется каждому, независимо от материального положения. И в этом смысле безусловный базовый доход выступает в качестве важного дополнения (а отнюдь не замены) социальному государству. В качестве же важнейшей меры для фи- 
нансового обеспечения базового дохода предлагается повышение налогов на богатство.

Кроме того, важным моментом посткапиталистического проекта, который предлагают Срничек и Уильямс, оказывается преодоление трудовой этики, ценностью которой является убеждение в том, что необходимо постоянно трудиться, чтобы «доказать свою ценность в глазах капитала» [7]. Однако работоспособность, требование постоянного труда, конкуренция - это как раз характеристики «неолиберальной субъектности», которая лежит в основе современного капиталистического общества. Напротив, посткапиталистический проект нацелен на расширение возможностей человечества, его освобождение, что, по словам авторов книги «Изобретая будущее», требует «новых когнитивных карт», новых «технологических интерфейсов» и экономических моделей [7].

В противовес неолиберальной идее «конца истории» и окончательной победы капитала Н. Срничек и А. Уильямс настаивают на «радикальной открытости будущего», необходимости заново создать будущее. Альтернативой универсальности капитализма являются новые универсальности, в основе которых лежит новое понимание «модерности», «новое будущее» и «освобождение».

Современный капитал и проблема неравенства. Идеи повышения налога на богатство и проблема неравенства находятся в центре исследовательского внимания Томаса Пикетти, автора известной книги «Капитал в XXI веке» [4]. Пикетти фиксирует существенный рост экономического неравенства в современном мире, что во многом напоминает ситуацию эпохи рантье начала XIX века, столь ярко описанную в классических романах Бальзака и Джейн Остин. Мир рантье это мир, в котором имущество производит ренту и при этом доходы с наследственного капитала существенно превосходят экономический рост. Исследуя на большом статистическом и историческом материале «долгосрочную эволюцию богатства», историческую динамику его распределения, автор убедительно показывает, что к началу XXI века происходит резкое усиление неравенства, «сил расхождения», которые характеризуются процессами «накопления и концентрации имущества на фоне слабого экономического роста и высоких доходов с капитала» [4]. При этом на фоне медленного экономического роста «огромный объем» накопленного капитала «может резко влиять на социальную структуру и распределение богатства» [4].

Выводы, к которым приходит Т. Пикетти, по его собственным словам, «не очень утешительны». По крайней мере, для него оптимистическая точка зрения, согласно которой «уравновешивающие силы роста, конкуренции и технического прогресса» способствуют сокращению неравенства и обеспечивают «гармоничную стабилизацию» общества, является весьма проблематичной. Как пишет Пикетти, «кажется, будто капитал исчез и мы, словно по волшебству, перешли от цивилизации, основанной на капитале, наследстве и связях, к цивилизации, основанной на человеческом капитале и личных достоинствах» [4]. Однако Пикетти призывает «остерегаться такого безмятежного оптимизма» [4].

Конечно, распространение знаний, инвестиции в человеческий капитал и образование направлены на сокращение социальноэкономического неравенства, являются в долгосрочной перспективе важным средством этого сокращения. Однако безудержная вера в образование и «меритократический идеал» во многом оказалась иллюзорной. При росте уровня образования и господстве «меритократической» установки с ее «культом труда» в современном обществе все-таки резко увеличивается неравенство. Наследственный капитал и доходы с него оказываются более эффективным способом достижения общественного успеха, нежели образование, личные достоинства и труд. И в этой ситуации существует «серьезный риск восстановления имущественного неравенства», которое сопоставимо с уровнем неравенства прошлых эпох и даже превышает его «при определенных условиях» [4].

Меры, предлагаемые Т. Пикетти для предотвращения подобного сценария, связаны с совершенствованием государственной политики в области налогообложения: автор «Капитала в XXI веке» предлагает ввести прогрессивный «всемирный налог на капитал». Называя этот налог «идеальной мерой» сокращения неравенства, Пикетти признает, что в мировом масштабе идея введения про- 
грессивного налога является пока еще утопией, но утопией «полезной». По крайней мере, считает он, прогрессивный налог на капитал, будучи «ключевым элементом социального государства», следует реализовать в региональном масштабе Европы.

Заключение. Можно сказать, что проблема современного капитализма все более остро ставится в современных социальных исследованиях. При этом социальные теоретики не только критически анализируют негативные тенденции современного общества, но и предлагают возможные проекты преодоления этих тенденций. Центральной проблемой и негативной тенденцией современного капитализма оказывается резкий рост неравенства, который может привести к «неофеодализму» (Дж. Дин). В качестве же альтернативы общественного развития предлагаются проекты «посттрудового» общества, основанного на «безусловном базовом доходе» (Н. Срничек, А. Уильямс). Весьма скрупулезный и убедительный анализ неравенства в современном мире представлен в теории Т. Пикетти (комментируя «Капитал в XXI веке», Пикетти отмечает, что эта книга - не только сугубо экономическая работа, но, прежде всего, труд по социальным наукам [5]). При этом в качестве важнейшей меры сокращения неравенства предлагается введение «всемирного» прогрессивного налога на капитал.

\section{Литература}

1. Андерсон П. Переходы от античности к феодализму. - М.: Территория будущего, 2007. - $288 \mathrm{c}$.

2. Дин Дж. Коммунизм или неофеодализм? // Логос. - 2019. - №6. - С. 85-116.

3. Дин Дж. Коммуникативный капитализм: от несогласия к разделению // Коммуникации. Медиа. Дизайн. - 2017. — Т. 2. №3. - С. 152-165.
4. Пикетти T. Капитал в XXI веке. - М.: Ad Marginem Press, 2015. — 592 c.

5. Пикетти T. К политической и исторической экономии. Размышления о капитале в XXI веке // Экономическая история. 2015. - №4. - C. 7-19.

6. Срничек H. Капитализм платформ. М.: Издательский дом Высшей школы экономики, 2019. - $128 \mathrm{c.}$

7. Срничек Н., Уильямс А. Изобретая будущее: посткапитализм и мир без труда. M.: Strelka Press, 2019. — 336 c.

\section{References}

1. Anderson P. Perekhody ot antichnosti $\mathrm{k}$ feodalizmu [Passages from antiquity to feudalism]. - Moscow: Territoriya budushchego, 2007. - $288 \mathrm{p}$.

2. Din Dzh. Kommunizm ili neofeodalizm? [Communism or neo-feudalism?] // Logos. 2019. — №6. — Pp. 85-116.

3. Din Dzh. Kommunikativnyy kapitalizm: ot nesoglasiya $\mathrm{k}$ razdeleniyu [Communicative capitalism: from dissent to division] // Kommunikatsii. Media. Dizayn [Communications. Media. Design]. — 2017. — Vol. 2. — №3. Pp. 152-165.

4. Piketti T. Kapital v XXI veke [Capital in the twenty-first century]. - Moscow: Ad Marginem Press, 2015. - $592 \mathrm{p}$.

5. Piketti T. K politicheskoy i istoricheskoy ekonomii. Razmyshleniya o kapitale v XXI veke [Towards a political and historical economy. Reflections on the capital in the twenty-first century] // Ekonomicheskaya istoriya [Economic history]. — 2015. — №4. - Pp. 7-19.

6. Srnichek N. Kapitalizm platform [Platform capitalism]. - Moscow: Izdatel'skiy dom Vysshey shkoly ekonomiki, 2019. - 128 p.

7. Srnichek N., Uil'yams A. Izobretaya budushchee: postkapitalizm i mir bez truda [Inventing the future: postcapitalism and a world without work]. - Moscow: Strelka Press, 2019. - $336 \mathrm{p}$. 


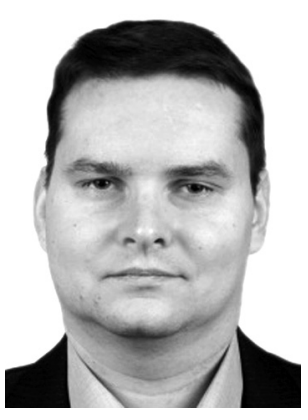

Павлов Павел Викторович - доктор философских наук, профессор кафедры «Управление персоналом» Южно-Российского государственного политехнического университета (НПИ) имени М.И. Платова.

Pavlov Pavel Viktorovich - Doctor of Philosophical Sciences, Professor, Department «Personnel Management», Platov South Russian State Polytechnic University (NPI).

346428 , г. Новочеркасск, ул. Просвещения, 132

132 Prosveshcheniya st., 346428, Novocherkassk, Russia

E-mail: pvpavlov2006@yandex.ru

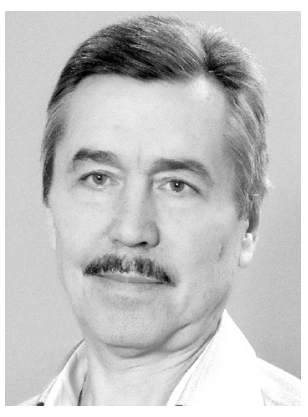

Любченко Василий Сергеевич - доктор философских наук, профессор кафедры «Юриспруденция, философия и история» Южно-Российского государственного политехнического университета (НПИ) им. М.И. Платова.

Lyubchenko Vasiliy Sergeyevich - Doctor of Philosophical Sciences, Professor, «Law, Philosophy and History» Department, Platov South Russian State Polytechnic University (NPI).

346428, г. Новочеркасск, ул. Просвещения, 132

132 Prosveshcheniya st., 346428, Novocherkassk, Russia

E-mail: sophiya_npi@mail.ru 